М. Є. Кушинська, О. Я. Чупашко, 3. Д. Воробець Львівський національний медичний університет імені Данила Галицького

\title{
НАУКОВО-ПЕДАГОГІЧНА ДІЯЛЬНІСТЬ ПРОФЕСОРА О. І. ЖУРБІНА - ЗАВІДУВАЧА КАФЕДРИ МЕДИЧНОЇ БІОЛОГІЇ (1949-1970)
}

\author{
M. Ye. Kushynska, O. Ya. Chupashko, Z. D. Vorobets \\ Danylo Halytskyi Lviv National Medical University \\ SCIENTIFIC AND PEDAGOGICAL ACTIVITY OF \\ PROFESSOR O. I. ZHURBIN - HEAD OF THE DEPARTMENT OF \\ MEDICAL BIOLOGY (1949-1970)
}

\begin{abstract}
Мета роботи - ретроспективне дослідження життєвого шляху та основних напрямків наукової діяльності завідувача кафедри медичної біології Львівського національного медичного університету імені Данила Галицького (1949-1970) професора Олексія Івановича Журбіна.

Основна частина. Висвітлено сторінки біографії, простежено становлення О. І. Журбіна як науковця, показано основні напрямки наукових досліджень у галузі ботаніки і паразитології. Зокрема, акцент зроблено на його дослідженнях з йодування рослинних продуктів харчування з метою профілактики та лікування ендемічного зоба та атеросклерозу, що не втратили актуальності дотепер. Проаналізовано наукові роботи професора О. І. Журбіна щодо виведення і розмноження нових гібридів тополь, для озеленення міст та екології видового складу синантропних мух і комарів Львівської області та Українського Полісся, їх епідеміологічне значення в поширенні гельмінтозів та інших захворювань людини. Наголошено, що науковою школою професора О. І. Журбіна були випробувані і запропоновані санепідемстанціям нові інсектициди для боротьби з мухами, комарами і клопами.

Висновок. Дане наукове повідомлення на основі аналізу архівних матеріалів працівниками кафедри медичної біології, паразитології та генетики дозволило висвітлити сторінки наукової біографії завідувача кафедри медичної біології професора О. І. Журбіна, проаналізувати його наукову спадщину, що стосувалась актуальних проблем ботаніки і паразитології.
\end{abstract}

Ключові слова: медична біологія; О. І. Журбін; цитогенетика рослин; декоративні рослини.

The aim of the work - retrospective research of course of life and basic directions of scientific activity of O. Zhurbin - the head of the Department of Medical Biology (1949-1970), of Danylo Halytskyi Lviv National Medical University.

The main body. The scientific article is devoted sanctified to the analysis of life and science path of the Head of the Department of Medical Biology at Danylo Halytskyi Lviv National Medical University (1949-1970), professor O. Zhurbin. The biography is reflected, becoming of $\mathrm{O}$. Zhurbin a scientist is traced and basic directions of scientific researches in industry of botany and parasitology are shown. In particular, an accent on his researches on iodization of vegetable foodstuffs with the aim of prophylaxis and treatment of endemic goiter and atherosclerosis, that did not lose actuality to this day is done. Scientific works of professor O. Zhurbin in relation to a leading out and reproduction of new hybrids of poplars for planting of greenery of cities as well as ecology of specific composition of synanthropic flies and mosquitoes of the Lviv area and Ukrainian Polissia, their epidemiology value in distribution of helminthes and other diseases of a man and analyzed. It is highlighted that new insecticides against flies, mosquitoes and bedbugs were tested offered to sanepidem units by scientific school of professor O. Zhurbin.

Conclusion. This scientific report based on the analysis of archival materials allowed highlighting the pages of the scientific biography of professor O. Zhurbin - the head of the Department of Medical Biology (1949-1970), to analyze his scientific heritage, which concerned current problems of botany and parasitology.

Key words: medical biology; O. Zhurbin; cytogenetics of plants; decorative plants.

Вступ. За майже столітню історію існування кафедри медичної біології Львівського національного медичного університету імені Данила Галицького на ній працювали вчені і створені ними потужні наукові школи, що провадили дослідження з різних напрямків медико-біологічної науки. Відомості про

() М. Є. Кушинська, О. Я. Чупашко, 3. Д. Воробець життя і діяльність цих вчених становлять безперечний інтерес у сенсі формування світоглядної позиції майбутнього лікаря як носія найгуманнішої професії. Засновником кафедри медичної біології був професор Рудольф Вейгль, який працював на цій посаді з 1920 до 1944 р. Його знає світова медико-біологічна наука як великого біолога, паразито- 
лога, мікробіолога, імунолога, що створив першу у світі ефективну вакцину для боротьби з висипним тифом. Завдяки працям Р. Вейгля кафедра медичної біології стала всесвітньо відомою і привабливою для світових учених. Наступником Р. Вейгля став професор М. Єфімов. За час його керівництва (1946-1948) кафедрою біології у Львівському медінституті співробітники кафедри відійшли від проблеми висипного тифу і зайнялися проблемою регенерації органів і тканин. У 1949 р. кафедру медичної біології очолив Олексій Іванович Журбін, його керівництво кафедрою тривало понад 20 років. Незабаром виповнюється 120 років від дня народження О. I. Журбіна, і дане наукове повідомлення присвячується висвітленню його життєвого і наукового шляху.

Мета роботи - ретроспективне дослідження життєвого шляху та основних напрямків наукової діяльності завідувача кафедри медичної біології Львівського національного медичного університету імені Данила Галицького (1949-1970) професора Олексія Івановича Журбіна.

Основна частина. О. І. Журбін народився 4 березня 1899 р. в селі Козельщина Полтавської області. Середню освіту отримав у реальному училищі Полтави 1917 р., в 1918-1920 рр. навчався у Харківському сільськогосподарському інституті, а в 1927 р. закінчив аграрний факультет Московської сільськогосподарської академії.

По завершенні навчання працював лаборантом Ташкентського відділення Інституту прикладної ботаніки у відділі селекції рослин (1928-1930), далі - науковим співробітником цитоанатомічної лабораторії Ташкентського НДІ бавовни (19301931), за сумісництвом - лаборантом кафедри ботаніки Ташкентського університету.

У 1932 р. його призначили завідувачем лабораторії цитогенетики селекційно-генетичної станції I. Мічуріна, а за сумісництвом працював лектором Центрального НДІ овочівництва та Інституту ім. І. Мічуріна. 31933 до 1934 р. - завідувач сільськогосподарських лабораторій Московського обласного управління виправно-трудових установ.

31934 до 1936 р. О. І. Журбін працював на посаді завідувача кафедри ботаніки Інституту ім. I. Мічуріна, далі - старшим науковим співробітником Московського НДІ буряководства (1936-1937). У 1937 р. його запросили до Узбекистану, і там О. І. Журбін керував лабораторією Ташкентського НДІ бавовни (1937-1940), а за сумісництвом читав лекції у Ташкентському інституті цитогенетики. Згодом обраний на посаду доцента Ташкентського педагогічного інституту (1940-1941); у роки війни працював старшим науковим співробітником Інституту ботаніки АН Узбецької РСР. У 1944 р. його запросили до Києва, і тут працював на посаді доцента кафедри генетики Київського університету (1944-1946). Наукова біографія О. І. Журбіна у Львові почалася з 1946 р.: у 1946-1948 рр. завідував кафедрою селекції Львівського сільськогосподарського інституту, паралельно керував лабораторією Львівського відділення НДІ лісівництва АН УРСР. У 1952 р. О. І. Журбін став докторантом Інституту ботаніки АН СРСР, по завершенні докторантури в 1956 р. захистив докторську дисертацію на тему “Ботаніко-географічне обгрунтування районування і шляхи покращення сортів картоплі у західних областях УРСР” і здобув звання доктора біологічних наук.

Цей період і наступні 10 років були найбільш продуктивними для кафедри біології. У цей час кафедра значно розширилася за рахунок приєднання кафедри ботаніки фармацевтичного факультету. Велика увага приділялася організації навчального процесу. На кафедрі обладнані студентські лабораторії, віварій, акваріуми, гербарій лікарських рослин, що давало можливість студентам працювати самостійно і здобувати практичні навички.

Наукова діяльність кафедри стосувалася, головним чином, розробки актуальних проблем ботаніки і паразитології. Професором О. І. Журбіним виконувалися роботи щодо виведення і розмноження нових гібридів декоративних рослин для озеленення міст, зокрема швидкоростучих тополь. Гібриди тополь були рекомендовані для озеленення промислових центрів і новобудов у Львівській, Дрогобицькій, Київській та інших областях України та по всьому Радянському Союзу. Також проведена робота з селекції далматської ромашки та інших лікарських рослин.

Також дослідження О. І. Журбіна були скеровані на вдосконалення методів йодування рослинних харчових продуктів для профілактики ендемічного зоба та атеросклерозу. 3 метою насичення йодом організму людини була розроблена методика, яка дозволяла збільшувати кількість йоду в сільськогосподарських культурах, зокрема в картоплі, кукурудзі, моркві, капусті і помідорах. Одержані йодовані культури використовувались як профілактичний засіб боротьби з ендемічним зобом. Актуальність наукових розробок щодо йодування продуктів харчування не втратила актуальності й сьогодні у зв’язку з подіями в Чорнобилі.

Другий - паразитологічний - напрям досліджень за керівництва О. І. Журбіна та співробітників ка- 
федри полягав у вивченні екології синантропних мух, видового складу мух і комарів Львівської області й Українського Полісся, біології, екології і фізіологічних особливостей найбільш поширених видів, їх епідеміологічного значення в поширенні захворювань людини та гельмінтозів. Науковою школою професора О. І. Журбіна були випробувані і запропоновані санепідемстанціям нові інсектициди для боротьби з мухами, комарами і клопами.

Олексій Іванович Журбін - автор близько 50 наукових праць, серед них 2 монографії, 2 підручники, підготував 5 кандидатів наук.

Основні праці: “Строение и развитие хлопчатника”, “Экспериментальная полиплоидия”, “Полиплоиды хлопка, полученные посредством колхицина”, “Ботанико-географическое обосно-

\section{Список літератури}

1. Ганіткевич Я. Українські лікарі-вчені першої половини XX століття та їхні наукові школи. Біографічні нариси та бібліографія / Я. Ганіткевич. - Львів : В-во НТШ, 2002. - 542 c.

2. Журбин А. И. Обогащение йодом растительных пищевых продуктов с целью профилактики эндемического зоба / А. И. Журбин // Актуальні проблеми медицини. - 1965. - С. 40-42.

3. Журбин А. И. Новые межвидовые гибриды тополей / А. И. Журбин // Ботанический журнал. - 1961. T. 46, № 5. - С. 710-718.

4. Зіменковський Б. С. Професори Львівського національного медичного університету імені Данила Галицького: 1784-2006 / Б. С. Зіменковський, М. Р. Гжегоцький, О. Д. Луцик. - Львів : Наутілус, 2006. - 416 с.

\section{References}

1. Hanitkevych, Ya. (2002). Ukrainski likari-vcheni pershoi polovyny XX stolittia ta yikhni naukovi shkoly [Ukrainian physicians-scientists of the first half of the twentieth century and their scientific schools. Biographical essays and bibliography]. Lviv: V-vo NTSh [in Ukrainian].

2. Zhurbin, A.I. (1965). Obogashchenie yodom rastitelnykh pishchevykh produktov s tseliu profilaktiki endemicheskogo zoba [Enrichment of plant foods with iodine in order to prevent endemic goiter]. Aktualni problemy medytsyny - Actual Problems of Medicine, 40-42 [in Russian].

3. Zhurbin, A.I. (1961). Novye mezhvidovye hibrydy topoley [New interspecific hybrids of poplars]. Botanicheskiy zhurnal - Botanical Journal, 46, 5, 710-718 [in Russian].

4. Zimenkovskyi, B.S., Hzhehotsyi, M.R., \& Lutsyk, O.D. (2006). Profesory Lvivskoho nactsionalnoho medychnoho universytetu imeni Danyla Haltsckoho: 1784-2006 [Professors of Danylo Halytskyi Lviv National Medical University: 1784-2006]. Lviv: Nautilus [in Ukrainian].

5. Lvivskyi jblasnyi derzhavnyi arkhiv [Lviv Regional State Archive] [in Ukrainian]. вание районирования и пути улучшения сортов картофеля в западных областях УССР”, “Ботаніка (підручник)”, “Ботаніка з основами загальної біології (підручник)”.

У 1970 р. О. І. Журбін за станом здоров’я залишив посаду завідувача кафедри біології Львівського медичного інституту і до 1972 р. працював професором-консультантом на цій кафедрі.

Висновок. Дане наукове повідомлення на основі аналізу архівних матеріалів науково-педагогічними працівниками кафедри медичної біології, паразитології та генетики дозволило висвітлити сторінки наукової біографії завідувача кафедри медичної біології (1949-1970) професора О. І. Журбіна, проаналізувати його наукову спадщину, що стосувалась актуальних проблем ботаніки і паразитології.

5. Львівський обласний державний архів, ф. 26, оп. 12 , од. зб. 469, л. 6-8.

6. Львівський державний медичний інститут. 210-річчю відкриття, 100-річчю відновлення медичного факультету у Львові присвячується. - Львів, 1994. - 328 с.

7. Середа О. М. Кафедра медичної біології Львівського національного медичного університету імені Данила Галицького: історичні та наукові аспекти розвитку / О. М. Середа, О. Я. Чупашко, 3. Д. Воробець // Медична освіта. - 2009. - № 3. - С. 57-60.

8. Шапиро И. Я. Очерки по истории Львовского медицинского института / И. Я. Шапиро. - Львов : ЛГМИ, 1959. - 135 c.

9. Ben Nefissa K. Charles Niccole's theory on the natural history of infectious diseases / K. Ben Nefissa // Arch. Inst. Pasteur Tunis. - 2006. - Vol. 83, No. 1. - P. 5-12.

6. (1994). Lvivskyi derzhavnyi medychnyi instytut. 210-richchiu vidkryttia, 100-richchiu vidnovlennia medychnogo fakultetu u Lvovi prysviachuietsia [Lviv State Medical Institute. The 210-th anniversary of the opening, 100-th anniversary of the restoration of the medical faculty in Lviv is devoted to. Lviv [in Ukrainian].

7. Sereda, O.M., Chupashko, O.Ya., \& Vorobets, Z.D. (2009). Kafedra medychnoi biolohii Lvivskoho natsionalnoho medychnoho universytetu imeni Danyla Halytskoho: istorychni ta naukovi aspekty rozvytku [Department of Medical Biology, Lviv National Medical University named after Danylo Halytskyi: historical and scientific aspects of development]. Medychna osvita - Medical Education, 3, 57-60 [in Ukrainian].

8. Shapiro, I.Ya. (1959). Ocherki po istorii Lvovskoho medicinskoho institutie [Essays on the history of the Lviv Medical Institute]. Lvov: LGMI [in Russian].

9. Ben Nefissa, K. (2006). Charles Niccole's theory on the natural history of infectious diseases. Arch. Inst. Pasteur Tunis, 83 (1), 5-12.

Електронна адреса для листування: Kaf_medicalbiology@meduniv.lviv.ua

Отримано 25.09.18 